\title{
Voces que construyen memoria colectiva. La dimensión inmaterial del patrimonio industrial en la Población Obrera Sociedad Explotadora de Tierra del Fuego, Punta Arenas, Chile
}

\author{
Voices that build collective memory. The intangible dimension of \\ industrial heritage of working class housing "Sociedad Explotadora de \\ Tierra del Fuego", Punta Arenas, Chile \\ Dr. Rodrigo Herrera Ojeda a ${ }^{a}$ Ms. Daniela Ambrosetti Garrido ${ }^{\mathrm{b}}$ \& Dr. Boris Cvitanic Díaz \\ aVicerrectoría Vinculación con el Medio, Universidad de Concepción, Chile \\ $\measuredangle$ rherrerao@udec.cl [orcid.org/0000-0002-8750-8936] \\ bAcadémica Departamento de Arquitectura, Universidad de Magallanes, Chile \\ daniela.ambrosetti@umag.cl [orcid.org/0000-0003-4671-3957] \\ 'Académico Departamento de Arquitectura, Universidad de Magallanes, Chile \\ boris.cvitanic@umag.cl [orcid.org/0000-0002-9008-6519]
}

\section{RESUMEN ${ }^{1}$}

La construcción de la Población Obrera Sociedad Explotadora de Tierra del Fuego, en la década de 1950 en la ciudad de Punta Arenas, significó, además de una manifestación de las lógicas del paternalismo industrial en la zona, la consolidación de una comunidad de vecinos que afianzó un fuerte lazo entre sí. Una vez que la industria ganadera se desprendió de las viviendas, en la antesala de su desaparición, aquella comunidad comenzó a disgregarse. El siguiente artículo explora en torno a la memoria colectiva que ha sobrevivido a aquel proceso de disociación, en tanto forma que busca evitar su desaparición y reivindicar un legado en el que se funden elementos arquitectónicos con dimensiones socioculturales.

PALABRAS CLAVE: industria ganadera, Población Obrera Sociedad Explotadora de Tierra del Fuego, memoria colectiva, patrimonio inmaterial.

\section{ABSTRACT}

The construction of the Working Class Housing "Sociedad Explotadora de Tierra del Fuego" in the 1950s in the city of Punta Arenas, meant, in addition to a manifestation of

1 El presente texto se inscribe dentro de la siguiente investigación: "Patrimonio Industrial: Formas de Habitar Colectivo en el sur de Chile”. Proyecto Anillos SOC 1403 de CONICYT. 
R. Herrera et AL.

industrial paternalism logics, the consolidation of a community of neighbors that strengthened a bond with each other. Once the livestock industry decided to get detached from the houses, in the prelude to its disappearance, this community began to disintegrate. The following article explores around the collective memory that has survived the dissociation process, in a way that seeks to avoid its disappearance and to claim a legacy in which both architecture and sociocultural dimensions merge.

KEY WORDS: Livestock industry, Población Obrera Sociedad Explotadora de Tierra del Fuego, Collective Memory, intangible heritage.

\section{INTRODUCCIÓN}

El crecimiento de la ciudad de Punta Arenas a partir de 1920, producto del aumento de su población, determinó la aparición de conjuntos habitacionales de distinta envergadura en la periferia de lo que hasta ese minuto correspondía al centro urbano (Zamora, 1975, p. 84).

Los conjuntos habitacionales fueron mayoritariamente generados por el Estado central, a través de la Caja de la Habitación Popular y, más tarde, de la Corporación de la Vivienda, como la Población Obrera Arturo Prat, la Población Punta Arenas, la Población Mauricio Braun, o la Población Juan Williams (Zamora, 1975, p. 88), y por el municipio local, como la población Barrio Obrero (Baeriswyl, 2001, p. 92). A su vez, emergieron ciertos conjuntos residenciales producto de asentamientos irregulares, como los casos de las poblaciones 18 de Septiembre y Calixto. Posteriormente, en la década de 1960, como resultado de la acción de las Asociaciones de Ahorro y Préstamo se gestaron conjuntos residenciales de menor envergadura, como la Copeaustral, Enápolis o 29 de Diciembre (Cvitanic et al. 2018).

Sin embargo, de manera temprana y excepcional, la empresa Sociedad Explotadora de Tierra del Fuego (SETF) inició, en 1952, la construcción de un conjunto residencial para trabajadores de sus predios ganaderos y sus familias (Ambrosetti et al. 2016). Esta solución habitacional, que consideró sesenta y dos viviendas entregadas en arriendo a sus moradores, presentó ciertas particularidades como mejoras técnicas y constructivas, terrenos con patio y antejardín y amplios espacios públicos, lo que sumado a la distancia con respecto al resto de la ciudad contribuyeron a destacar su singularidad en el contexto urbano de la ciudad de Punta Arenas, redundando "en un particular modo de vida" (Ambrosetti et al. 2016, p. 127). Como consecuencia de la transformación social y política que supuso la implementación de la Reforma Agraria (Furche, 2017, p. 115), e inserto en el proceso de disolución de la Ganadera de Tierra del Fuego -continuadora comercial de la Sociedad Explotadora de Tierra del Fuego-, entre los años 1967 y 1972, la empresa decidió la venta de las viviendas. Si bien no existe certeza respecto al porcentaje de trabajadores residentes que lograron acceder a la vivienda a través de su compra, esta eventualidad se sitúa como un hito que marca un antes y 
un después en la dinámica social y material de una Población cargada de valor arquitectónico e histórico (Ambrosetti et al. 2016).

Tanto la desaparición de la empresa sostenedora, como la transformación del grupo humano que conformó el conjunto residencial en la época en que formaba parte de la empresa, incidieron en su paulatina transformación, ya sea en sus aspectos arquitectónicos, como también en el entramado de relaciones sociales que la volvió singular. Posiblemente ligado a esta condición de pérdida, pero igualmente a la reivindicación de una manera de hacer ciudad, en la recopilación de un conjunto de voces de vecinos y ex-vecinos es posible advertir la especial valoración de aquella experiencia común, ya no posible de reproducir, alojada en relatos que rememoran tiempos anteriores manifestándose, a la vez, como parámetros para evaluar el presente. La reivindicación es sobre una experiencia colectiva, donde se destaca todo un conjunto de valores aglutinantes que estructuraban la vida social del conjunto habitacional, transformando a éste en un barrio y, a los vecinos, en una gran familia. El objetivo del presente artículo es mostrar la estructuración de estas narrativas y sus fuertes concomitancias entre sí, para al mismo tiempo indagar en lo que significa la posibilidad de que esta memoria colectiva esté fuertemente vinculada a un determinado espacio construido, conformándose un espacio social en el que las representaciones sociales deben tanto a los acontecimientos y sus actores, como a los lugares donde aquellos ocurrían.

\section{ANTECEDENTES CONCEPTUALES}

Ambrosetti et al. (2016) destacaron las particularidades arquitectónicas y urbanas del conjunto residencial. Dicha aproximación permite vislumbrar valores patrimoniales tangibles e implícitos en la dimensión material de la población. Sin embargo, aproximaciones recientes defienden la doble condición del patrimonio, tanto material como inmaterial (Álvarez, 2008; Homobono, 2008; Pardo, 2016), donde no se lo reduce exclusivamente a bienes muebles (manuscritos, documentos, fotografías, etc.) o bienes inmuebles (conjuntos arquitectónicos, monumentos, etc.), sino que se trata de un fenómeno vivo, en permanente cambio y construcción, "fruto de la inventiva de las sociedades y de los grupos que las constituyen; de la identidad, de la memoria y del saber de los mismos" (Homobono, 2008, p. 58). En aquella dimensión se incorporan elementos intangibles como lenguajes, costumbres, expresiones musicales y otro tipo de elaboraciones colectivas que rearticulan determinados espacios sociales a través de relaciones sociales particulares, que pasan a ser consideradas como únicas. En este sentido, se establece que lo que adquiere valor patrimonial no es tanto un objeto o una materialidad, sino una especial relación establecida entre entidades físicas o inmateriales, y sujetos que les otorgan atributos especiales, en lo que es un continuo proceso de configuración de sistemas simbólicos que otorguen sentido a la realidad desde el presente (Maillard, 2011). En este contexto, el valor de lo testimonial no está tanto en un pasado rescatado de modo fiel, sino en la relación que en el presente establecen ciertos sujetos, o 
grupos, con los objetos de la memoria que constituyen testimonios de una realidad de la cual ellos también forman parte (DIBAM, 2005) y que, necesariamente, buscan la manera de perpetuarse en las nuevas generaciones.

En el caso que nos convoca consideramos que, en ocasiones, la experiencia social se guarda y transmite de forma compleja, entendiendo que no sólo el contenido otorga valor a los relatos, sino también a aquellas referencias simbólicas que, a través de ellos, convocan y reviven un colectivo. Los recuerdos, antes que simples relatos fortuitos, conforman imágenes narrativas asociadas a momentos pasados, que renuevan los significados comunes, cuyo objetivo no sería únicamente transmitir sino también otorgar vigencia a un sistema de valores, no individual, que no encuentra su lugar en el presente. A ello es lo que se le denomina memoria colectiva, en tanto proceso de construcción social, interactivo y colectivo, de selección, interpretación y transmisión de símbolos a través de los cuales se siente representada una colectividad (Halbwachs, 2004). Y, como forma de organizar las experiencias, lo más importante no está necesariamente en el ámbito de los contenidos que genera, sino en el hecho de ser construida por la interacción social -por tanto, compartida (Rosa, Bellel \& Backhurst, 2000)-, acabando por transformar en hitos articuladores de la vida social ciertos episodios vividos en común (Jelin, 2002). Hay un valor en lo que los testimonios dicen, pero más aún en su capacidad de aglutinar y producir algo de ese aglutinamiento.

Este proceso moldea un pasado desde el presente en donde, desde un sistema de valores que reproduce lo vivido a través de recuerdos, también actúa el olvido (Augé, 1998). De ahí su importancia en tanto condicionante de los vínculos sociales vigentes, al insertar éstos dentro de un contexto mayor en el que el presente es leído e interpelado, entre otras cosas, a partir de aquel pasado reelaborado. En ello radica la importancia de los marcos sociales que se promueven, en tanto sistemas lógicos y de sentido, cronológicos y topográficos, que ponen a disposición de quienes hacen el ejercicio de recordar un sistema general del pasado, designando el papel y el lugar de este para el presente. Es tan importante lo que se evoca, como lo que se omite.

\section{METODOLOGÍA}

El presente artículo se inscribe en un proyecto PIA Anillos CONICYT que integró las miradas de la arquitectura, como forma de ocupación de un territorio, con las fuentes orales y documentales trabajadas por las ciencias sociales, en el contexto de los procesos de industrialización y posterior desindustrialización, en el sur de Chile. El objetivo general del proyecto era comprender las formas de habitar colectivas asociadas a conjuntos habitacionales que podrían inscribirse como formas de patrimonio industrial, incluyendo los aspectos morfológicos y de habitar asociados, intentando articular dimensiones materiales e inmateriales del patrimonio industrial. 
Desde un punto de vista metodológico, se recopiló información de primera fuente a través de entrevistas semi-estructuradas, las que se llevaron a cabo tanto en dependencias del Departamento de Arquitectura de la Universidad de Magallanes, el día 26 de mayo de 2017, a una persona nacida en la Población que actualmente reside en otro sector de la ciudad, como en las viviendas de antiguos residentes que aún viven en la Población, realizadas el día 29 de mayo de 2017, siendo tres en total. Además, se realizó un taller de recopilación de memoria con vecinos y ex-vecinos de la Población Obrera Sociedad Explotadora de Tierra del Fuego, llevada a cabo el día 27 de mayo de 2017 en la sede de la Junta de Vecinos $\mathrm{N}^{0} 5$ de la misma Población y que contó con diez asistentes (Fig. 1).

Por otro lado, en base a la revisión de bibliografía específica se contextualizaron y consideraron los criterios y políticas de poblamiento, edificación y habitación de sectores ligados al desarrollo industrial en Magallanes. A la vez, se llevó a cabo un trabajo de archivo que permitiera contrastar los cambios de propietarios en la conformación del conjunto residencial.

Cabe señalar que se ha omitido personificar los testimonios orales recopilados, entendiendo también que su valor está en su fuerza colectiva, antes que en las características individuales de quienes los emitieron en su momento.

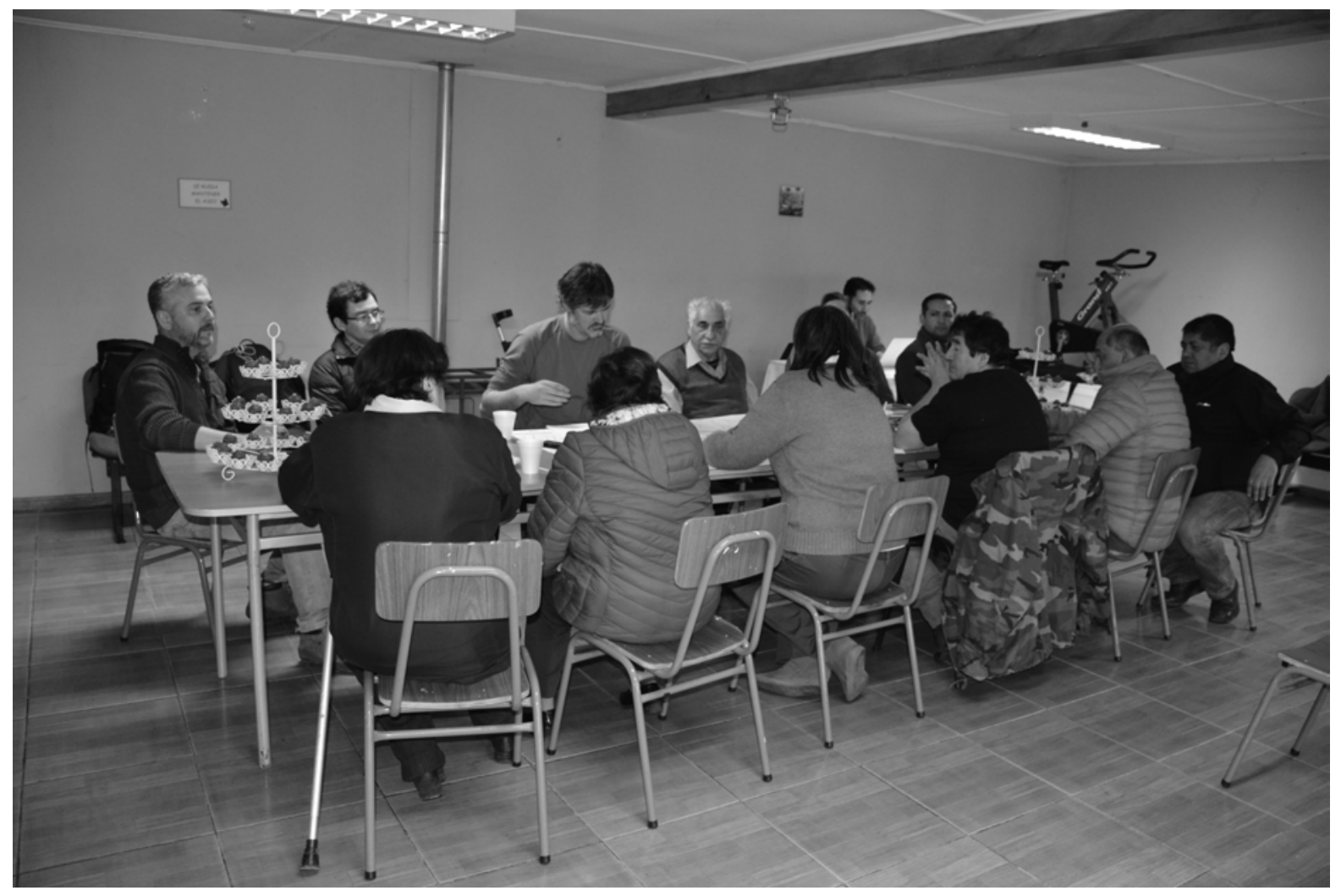

Fig. 1. Fotografía del Taller Participativo de Memoria Colectiva en la sede de la Junta de Vecinos No5 "Población Explotadora”. Fuente: Archivo fotográfico Daniel Matus Carrasco. 


\section{INDUSTRIA Y OCUPACIÓN DEL TERRITORIO}

En la región de Magallanes, el proceso de ocupación del territorio ocurrido a partir de la segunda mitad del siglo XIX fue, en términos generales y exceptuando los asentamientos de Fuerte Bulnes (1843) y Punta Arenas (1848), resultado de la implantación de actividades industriales concatenadas (Cvitanic \& Matus, 2018). La ganadería de extensión, la industria frigorífica, la industria forestal, la minería del carbón y el cabotaje marítimo se entrelazaron en una red productiva, de capitales y de enclaves industriales (ibíd.) que, junto con otras actividades puntuales como la industria ballenera (Nicholls, 2010), la actividad misionera (Martinic, 2011), o la minería aurífera en ciertos puntos de la región (Martinic, 2003), determinaron la ocupación y explotación del ecúmene regional (Martinic, 1980). Este proceso, que declina en términos generales hacia la mitad del siglo XX, se vio complementado por el descubrimiento del petróleo en 1945 y la posterior instalación de la industria extractiva y de procesamiento de hidrocarburos que conllevó profundas transformaciones en términos del territorio y de su grupo humano (Acevedo \& Rojas, 2014).

En la historiografía regional, el poblamiento ligado al proceso industrial de la región de Magallanes guarda una bitácora de relatos que involucran epopeyas y pioneros que habrían conseguido, con más imaginación que ciencia, poblar un territorio en condiciones marcadamente adversas. Así ha quedado testimoniado en la literatura relativa a la exploración y explotación del petróleo (Martinic, 1993, 2005; Fugellie, 199; Jofré, 1995; Acevedo \& Rojas, 2014), pero también al poblamiento del territorio que venció al aislamiento y lo desconocido ligado a la industria ganadera y sus derivados (Durán, 1943; Bascopé, 2008, 2010; Bayer, 2009; Martinic, 2011, 2017; Venegas, 2011; Garcés et al. 2013).

El sistema de producción industrial establecido en el territorio austral, precario en sus inicios (Cvitanic \& Matus, 2018), incorporó prontamente mejoras en las condiciones laborales y en la calidad de vida de los obreros, las que a su vez se hicieron extensivas a los tiempos del no-trabajo (Sierra, 1990; Vergara, 2013) lo cual, en el contexto nacional, fue resultado de reivindicaciones obreras (Salazar \& Pinto, 2014), de prácticas empresariales (Martinic, 2011) y de la acción del Estado (Hidalgo, 2005).

Es el período de despliegue del llamado 'paternalismo industrial', en tanto marco particular sobre el cual se instituyeron y desplegaron relaciones sociales vinculantes entre patrones y obreros, para crear lo que algunos llaman "una comunidad de destino" (Frey, 1987). El contexto global indicaba que los procesos de industrialización y modernización requerían de nuevas prácticas empresariales que se tradujeran en nuevos hábitos, disciplinas y normas, con el fin de permitir el desarrollo de otro tipo de habilidades y técnicas por parte de los trabajadores, para responder a las demandas del modelo capitalista (Hobsbawm, 1998). Para ello, era necesario hacer más eficiente el reclutamiento laboral, disminuir el absentismo y aumentar la capacitación de la mano de obra, consiguiendo así el aumento de la productividad. Estos esfuerzos no 
serían suficientes si no iban acompañados por beneficios sociales y servicios urbanos que acabarían creando mano de obra estable y productiva. Dentro de ellos, uno de los aspectos ampliamente consensuados fue el acceso a la vivienda por parte de los obreros, de manera de estabilizar no sólo al trabajador a través de un vínculo material, sino también para robustecer la figura de la familia que lo acompañaba (Godoy, 2015).

Igualmente, siguiendo estrategias propias de la particular geografía y las condiciones climáticas de la zona, en los escasos centros urbanos el desarrollo industrial, ganadero y de hidrocarburos preferentemente, ensayó también sus propias formas para hacer frente a las necesidades de localización y radicación de la mano de obra requerida para sus faenas (Matus \& Cvitanic, 2016). En este sentido, construida entre los años 1952-53 para subsanar en parte las necesidades de vivienda de los obreros que trabajaban en las estancias de la mayor empresa ganadera de la Patagonia (preferentemente obreros de las estancias Oazy Harbour y Punta Delgada, ubicadas en territorio continental), la "Población Obrera Sociedad Explotadora de Tierra del Fuego" en la ciudad de Punta Arenas, vino a ofrecer una solución de radicación a una parte de sus empleados y trabajadores (DOM, 1952, s.p.), estableciéndose como el primer caso de paternalismo industrial en el contexto austral (Ambrosetti et al. 2016).

\section{La Población obrera}

La Población Obrera Sociedad Explotadora de Tierra del Fuego, ideada por la empresa ganadera homónima, persiguió satisfacer las necesidades habitacionales de sus propios trabajadores declarando "cumplir de esta manera una finalidad social otorgando mejores condiciones de vida al obrero y su familia, y contribuyendo así a levantar el nivel de vida del obrero de la zona" (DOM, 1952, s.p.). El conjunto habitacional, proyectado por el arquitecto Arturo Calvo Hurtado y materializado por la empresa constructora Sociedad Salinas, Fabres y Avilés Ltda., se construyó en 1952 en el sector periférico norte de la ciudad de Punta Arenas, en un terreno de 5,2 hectáreas adquirido de la Sociedad Vicente y Antonio Kusanovic, colindando al Este con un terreno de propiedad de los mismos vendedores, por donde actualmente pasa la calle Uruguay, con Avenida Bulnes al Oeste, con la futura calle Enrique Abello al Norte y con la futura calle Manantiales al Sur; límites que respondían al plano de hijuelación que fuera base para el tejido urbano actual.

El proyecto habitacional sufrió una serie de alteraciones. Finalmente, se construyó la urbanización del conjunto y una plaza en su centro, que fue destinada a juegos infantiles. De las 138 viviendas propuestas en el primer diseño de 1951, que consideraba tres modelos distintos de dos, tres y cuatro dormitorios (DOM, 1952, s.p.), sólo se construyeron sesenta y dos unidades en la sección poniente del predio, distribuidas en dos modelos. Se trató de seis unidades bifamiliares aisladas (tipo A) de 76,61 m2, y cincuenta unidades unifamiliares pareadas (tipo B) de 95,44 $\mathrm{m}^{2}$. El resto del predio, correspondiente a la sección oriental, 
fue posteriormente vendido a trabajadores de la Empresa Nacional del Petróleo que, en 1966, edificaron la Población Enápolis. (Cvitanic et al. 2018, p. 103). Cabe destacar que si bien inicialmente no se contempló equipamiento complementario al habitacional, algunas viviendas fueron destinadas para otros usos, como lo fueron la vivienda para el cuidador del conjunto, una sede para reuniones y un predio destinado a la maestranza.

El conjunto habitacional, inaugurado parcialmente el 17 de enero de 1953, permaneció en propiedad de la Sociedad Explotadora siendo entregado en arriendo a sus trabajadores. De acuerdo a lo informado a la prensa por el gerente de la Asociación de Ganaderos, Sr. Enrique Donoso Bañados, se tendría como preferencia al personal más antiguo, fijando el costo “de acuerdo con sus posibilidades económicas” (El Magallanes, 1953, p. 7). Las viviendas fueron destinadas a mecánico, chofer, dibujante, cuidador, carpintero (Fig. 2), entre otros, además de obreros que trabajaban por rol en las estancias.

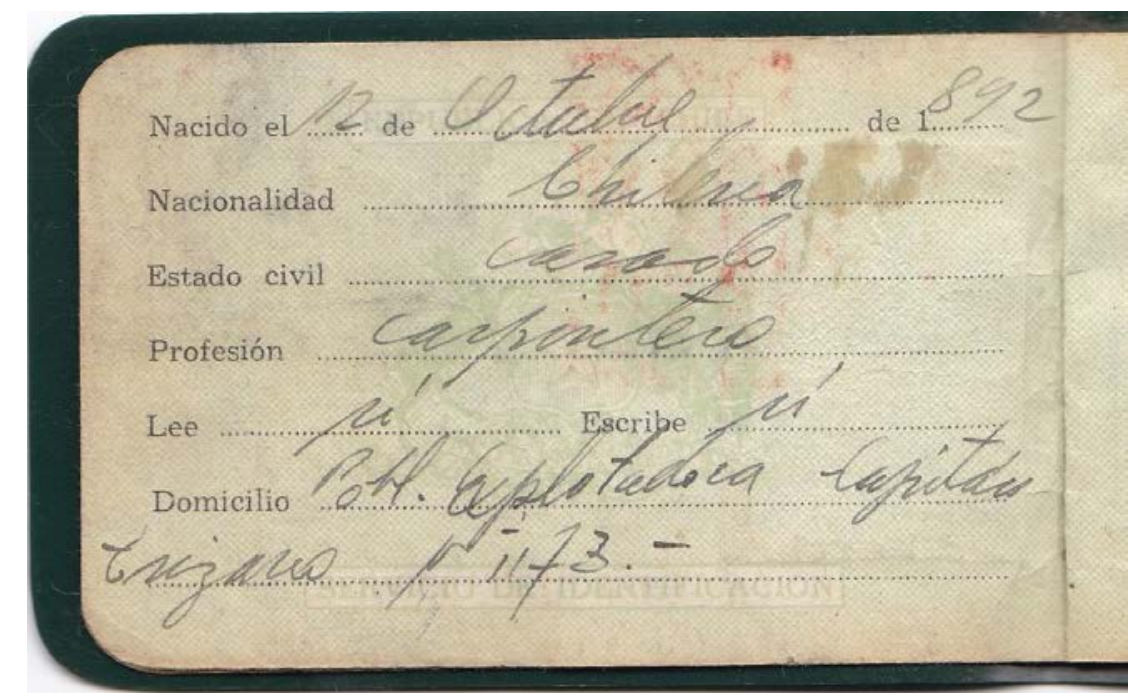

Fig. 2. Cédula de identidad del primer poblador del conjunto habitacional de la Sociedad Explotadora, carpintero y cuidador de la Población, en donde se indica el domicilio que fuera comprado en 1971 por sus descendientes. Fuente: Gentileza de Liliana Córdova Sandoval.

En el mes de enero de 1967 la empresa inicia la venta de las viviendas, proceso que dura hasta fines de 1972 (Fig. 3). Según registros de propiedad del Archivo del Conservador de Bienes Raíces de Magallanes (Registro Conservatorio de propiedad 1966, 1969, 1970, 1971 y 1972) se sucedió una serie de compraventas de los inmuebles involucrados, las que habrían sido realizadas siguiendo los precios referenciales del mercado inmobiliario, sin considerar facilidades para la adquisición de la vivienda por parte de los trabajadores de la empresa residentes. Bajo esta figura, el mismo relato oral indica que algunos de los antiguos propietarios pudieron comprar, aunque no fue una práctica extensiva ni posible de realizar por todos, dado el alto precio de venta de las viviendas. 

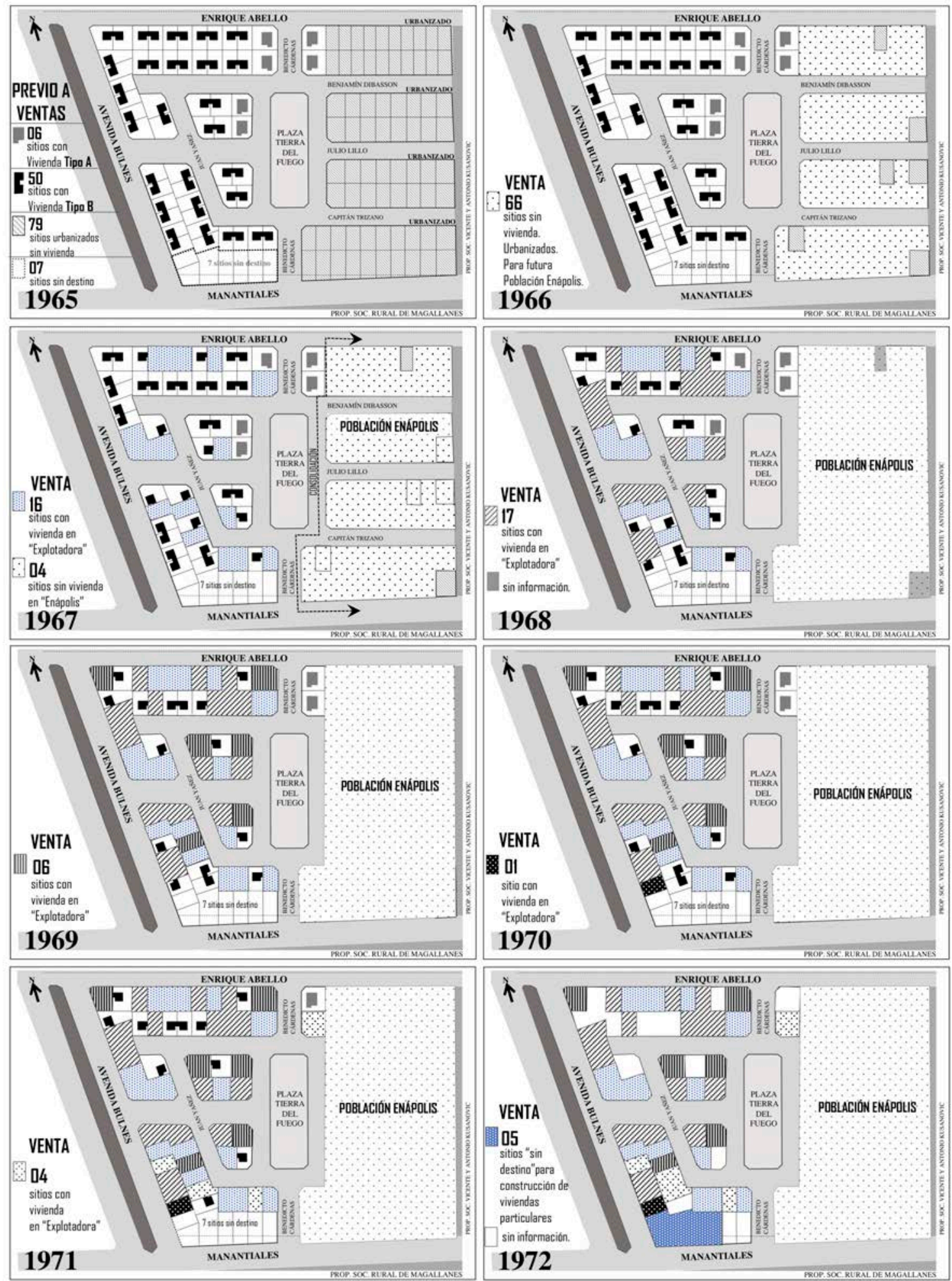

Fig. 3. Planimetría esquemática del proceso de cambio de propietarios del conjunto habitacional. Fuente: Elaboración de los autores. Dibujo Daniela Ambrosetti G., en base a original (DOM, 1952). 


\section{Memoria social en la Población Obrera. El pasado contenido en el presente}

Es en este paisaje urbano donde se ha configurado una memoria social, presente en los relatos de habitantes y ex-habitantes, conformando una compleja trama que ejerce un complemento al conjunto arquitectónico y urbano que moldea el espacio social en el momento actual. Para ello, la memoria recurre a un conjunto de imágenes que buscan expresar valoraciones colectivas. Y lo hacen insertándolas dentro de una arquitectura de lugar, que habría albergado y permitido aquella malla de vínculos que ya no es observable a simple vista (Fig. 4). Pero, además, asumiendo la amenaza de transformación radical de las antiguas viviendas que permitían una determinada experiencia colectiva. Debido a ello, los relatos no se precipitan a describir a partir de una cronología de sucesos sino, antes bien, delimitan un tiempo a partir de imágenes que el presente ya no puede albergar, las que están principalmente ancladas en ciertas fiestas significativas.

"Y lo que era navidad o año nuevo, se formaban los grupos de los adultos, de los jóvenes, los medianos y los chicos, y se recorría casa a casa, saludando y todo eso. Y en todas las casas nos esperaban, se esperaba que se pasara. Además, la navidad se hacía con un viejo pascuero que llegaba en un camión con regalos para todos. Y eran buenos regalos, no eran cualquier cosa" (Entrevistado $\mathrm{n}^{0} 1,26$ de mayo de 2017).

"Para las navidades todos recibíamos el mismo regalo. Yo lo que más me acuerdo es una vez en que a los chicos les llegó una bicicleta y a las chicas un reloj pulsera. Me acuerdo, porque eran como muy modernas para su época, eran bonitas, Bianchi. Y entonces todos tenían la misma, pero de distinto color" (Entrevistada n²2, 29 de mayo de 2017).

"No había clases sociales, a pesar de que, entre comillas, la población estaba dividida, porque la habían construido así. Todo se compartía, había muy poca pelea entre los niños, cuando las había se conversaba y se resolvía el problema. Y los vecinos eran muy buenos vecinos" (ibid.).

Lógicamente, este proceso evocativo va delimitando ciertos espacios que se van conformando como escenarios de mayor relevancia, en tanto lugares donde ocurría una sociabilidad propia, intensa, exclusiva, mas no excluyente para el grupo de vecinos. En esta indiscutible jerarquización espacial destaca un carácter público -o abierto- de aquellos lugares.

"Aquí había mucha convivencia, se compartía. Si en las tardes la plaza estaba llena, pero llena de niños...Y uno salía todo el rato. Se celebraban los cumpleaños, se hacían fiestas en la sede, se elegía reina, estaba el club deportivo..." (ibíd.).

"Yo tengo mis hijas mujeres...y con ellas disfrutamos acá...jugamos siempre en 
la plaza. Ellas vivían acá en la plaza, jugando acá a la pelota y esas cuestiones. Ellas su infancia la pasaron acá" (Participante taller $\mathrm{n}^{0} 4,27$ de mayo de 2017).

"Nosotros acá nos sacábamos 5, 6 pichangas de fútbol acá en la plaza, los viejos nos venían a buscar acá, tragábamos y partíamos otra vez. La última pichanga era a las 9, 10 de la noche. Jugábamos al pillado, a la ronda, las chicas al tejo..." (ibíd.).

"La base de la amistad que surgió entre todos nosotros fue la plaza. Esa plaza era muy especial en su época... La plaza era el lugar de encuentro en la Población... todo giraba en torno a la plaza" (Entrevistado ${ }^{0} 1,26$ de mayo de 2017).

"Después del colegio nos juntábamos todos acá, a jugar a la pelota, a la mancha, tocar timbres, a quebrar vidrios..." (Participante taller $n^{05}, 27$ de mayo de 2017).

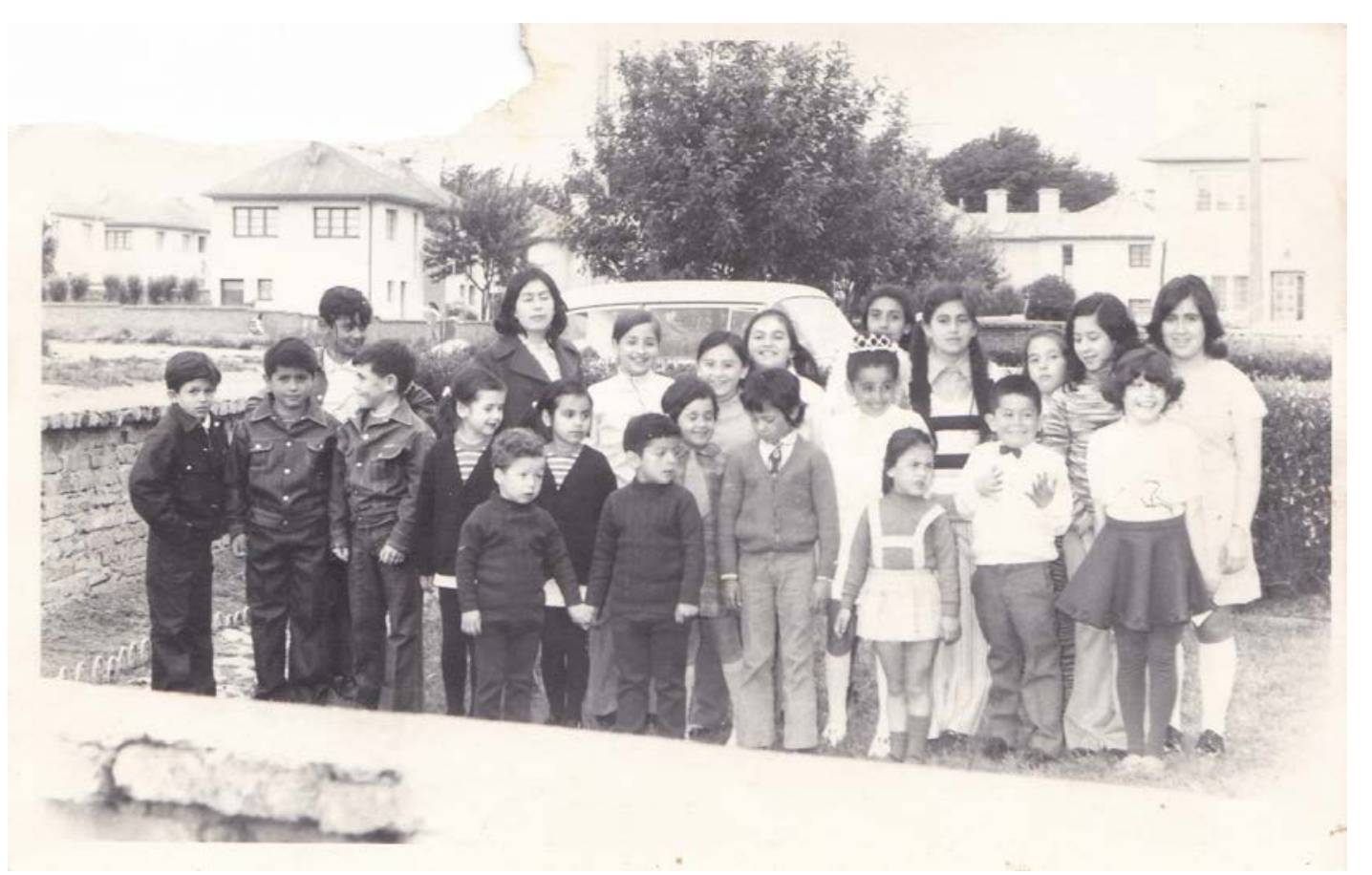

Fig. 4. Celebración de Primera Comunión en el patio de vivienda ubicada en esquina norponiente de calles Benedicto Cárdenas y Julio Lillo (1972). Fuente: Gentileza de María Angélica Santana Cárcamo.

Aquí es donde cobra relevancia el marco que permite organizar los recuerdos, al situarlos como expresiones simbólicas que, por sobre todo, buscan reafirmar el valor de lo común por sobre lo individual. No se pone en discusión la existencia de los espacios en la actualidad -la plaza, la sede, los patios de las viviendas, antes bien, sería que ellos ya no albergan aquellas prácticas que los definían anteriormente como espacios significativos. Entonces, a lo que verdaderamente remiten las evocaciones es que se ha transformado el valor de los distintos espacios, asumiendo que ya no cabe la anterior reproducción espacial y, por tanto, las relaciones que aquél cobijaba. 
"Nosotros, cuando ahora nos juntamos, añoramos las vivencias de esa época. Porque era otra vida; no había maldad, las casas abiertas. Ahora uno va a la Población y es otra cosa, ya no es lo mismo" (Entrevistada n², 29 de mayo de 2017).

“Ahora han cambiado los tiempos, ya no existen las personas que en su mayoría quedaron allí...Uno sabe todo esto, porque uno está siempre conectado. Hasta tenemos una página en Facebook y ahí uno se va enterando de las cosas...y estamos todos conectados" (Entrevistado nº1, 26 de mayo de 2017).

"Y los vecinos eran muy buenos vecinos. Ahora tú ves, han llegado muchos nuevos vecinos y tú puedes estar afuera y salen los vecinos y ni saludan...Por cortesía, digo yo." (Entrevistada n³, 29 de mayo de 2017).

"Lo que quedó acá fueron muy bonitos recuerdos, para todos los que vivimos acá. Yo intenté que mi hijo, cuando veníamos de visita a ver a mi papá, se incorporara acá con los niños que se veían, pero ya no era lo mismo. Los papás compartían, jugaban pichangas” (Entrevistada nº3, 29 de mayo de 2017).

Siguiendo la literatura especializada (Augé, 1998; Halbwachs, 2004), un propósito de todo marco de organización de recuerdos es proponer, a través de los relatos, claras diferencias entre el pasado y el presente. Esta separación tácita se erige en herramienta que permite otorgarle un lugar al presente, el que al ser percibido en oposición al pasado encuentra un sentido y un marco desde el cual ser percibido. Para ello, parece ser determinante establecer una bisagra entre un antes y un después, de manera de otorgarle fuerza a la evocación partiendo de la distancia entre uno y otro, permitiendo a la vez poder asimilar lo reciente y mantener vigente lo pretérito.

En el caso de la Población, se alude permanentemente a un hecho que haría las veces de corte temporal: la venta de las viviendas por parte de la Sociedad Explotadora de Tierra del Fuego, a precio de mercado, sin facilidades en la adquisición para quienes hasta ese momento las habitaban, los empleados y trabajadores de la propia empresa. No todos sus moradores tuvieron los recursos necesarios para adquirirlas, debiendo desalojar las viviendas. Ello habría redundado en su dispersión por la ciudad al punto de que, en muchos casos, perdieran todo contacto, más que con el lugar, con el resto de pobladores.

“En los años '70 ya las casas pasaron a ser de propiedad de las personas que decidieron comprar...de los obreros no fueron muchos...bueno, algunos se fueron a la Población Fitz Roy" (Participante taller nº6, 27 de mayo de 2017).

El hito, en este sentido, indica que la cercanía que definía la colectividad era tanto física como social, permitiendo tener una experiencia de lugar compleja y única a la vez. También, de forma implícita, se manifiesta cómo las transformaciones derivaron en la sensación de pérdida de lugar. 
"Los nuevos dueños [de las viviendas] son desconocidos, compraron las casas. Ellos no saben mucho, no añoran lo que nosotros vivimos, porque su vida fue distinta" (Entrevistada n², 29 de mayo de 2017).

Pero frente al desarraigo espacial que ofrece el presente, el tiempo pasado ofrece un vínculo con el lugar (Fig. 5). Los testimonios proponen un pasado mistificado, a manera de estrategia de apropiación en un presente en el que ya no se encuentran elementos de identificación como colectivo. Se relevan y exaltan cualidades de otros tiempos, como la comunión entre los habitantes de la Población que iba más allá de las fiestas o eventos sociales y podía verse en el día a día; la buena vecindad, expresada como tan distinta a la actual donde "casi ni se saluda al vecino", ni siquiera por la cercanía física; la propia solidaridad para enfrentar problemas que asumían como comunes; la seguridad que daba el poder recurrir a los vecinos por ayuda; la amistad cultivada desde niños, o a través de los hijos que se reunían a diario en cualquier casa, o en la plaza. Todos valores a través de los cuales el pasado se contrapone al presente y los juzga.

"Vivíamos muy aclanados. No había teléfonos, sólo uno, que era el teléfono del chofer del Gerente y él tenía teléfono por si lo necesitaban. Entonces, uno salía a jugar y llegaba la hora de almuerzo y uno almorzaba donde te pillaba el juego, como eran casas abiertas, estaban abiertas para todos. Lo mismo, si días después estabas jugando

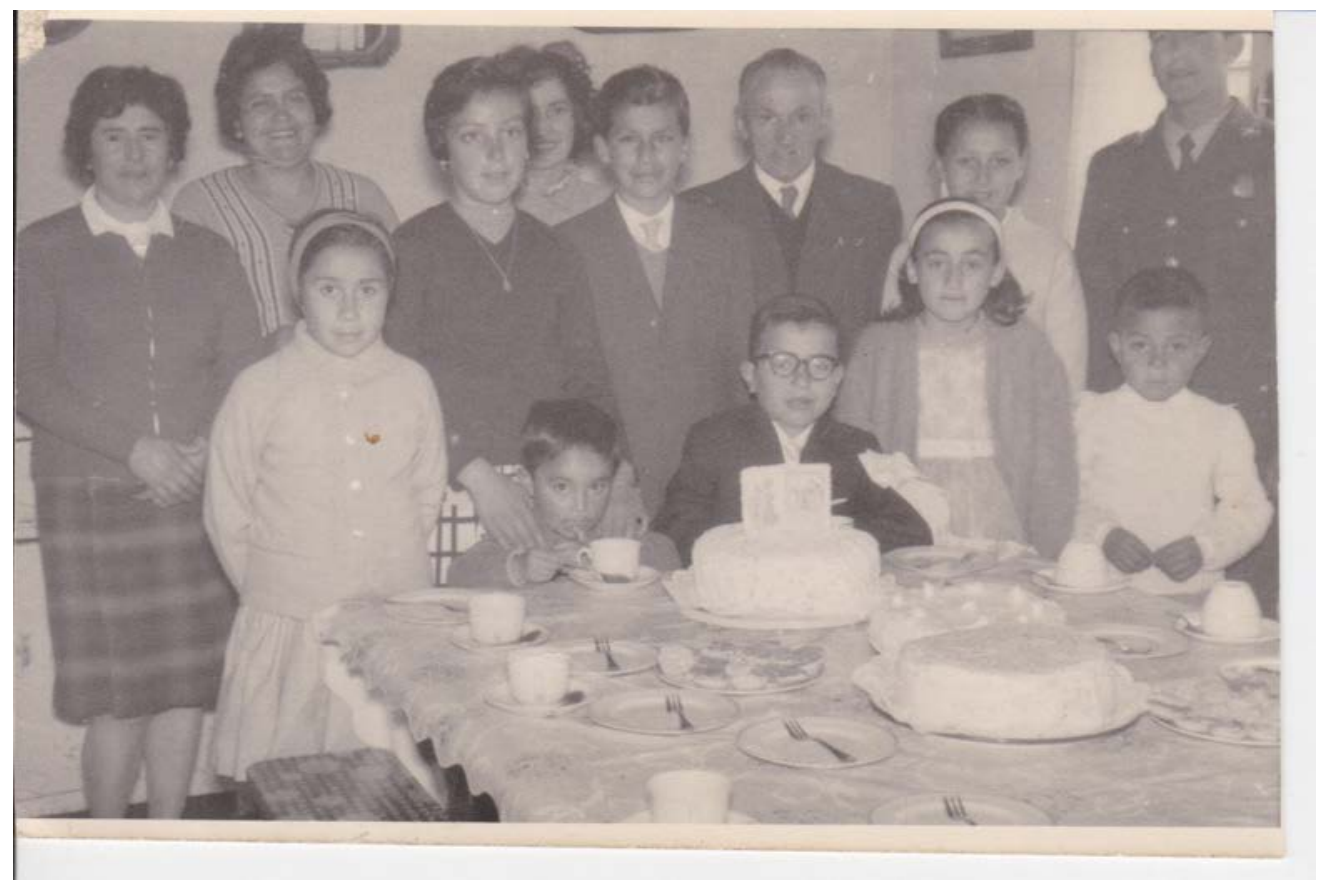

Fig. 5. Fiesta de Primera Comunión celebrada por niños y adultos al interior de una vivienda (1965). Fuente: Gentileza de Margarita Alarcón Flores. 
y te pillaba la hora de once, entrabas a la casa de alguien a tomar la once. Así era" (Entrevistado $\mathrm{n}^{0} 1,26$ de mayo de 2017).

Ahora bien, en este mismo proceso de construcción de imágenes con sentido que hablan por otro tiempo, los silencios u omisiones también adquieren significado. Si asumimos que en la elaboración de percepciones los distintos elementos son ordenados en términos jerárquicos por su relevancia colectiva, aquellos que se suprimen, o no se revelan, tienen menos trascendencia. En este caso, no hay mayores alusiones a aquellos aspectos que podrían haber reflejado algún tipo de disconformidad con la empresa. Al respecto, por ejemplo, destaca la escasa importancia que adquiría el modelo de trabajo implementado por la industria ganadera en relación a sus trabajadores, bajo los designios del llamado paternalismo industrial. En el caso específico, estando las estancias lejos de la ciudad, se implementó el sistema "por rol", lo que implicó largas ausencias de los trabajadores hombres en la Población, que no se reflejan en la vida cotidiana antes remarcada.

“Cuando yo ya cumplí dos años, le dieron casa a mi papá. Eso fue el año ’59. Se vino mi mamá conmigo, mi papá se quedó trabajando. Bajaba cada tres meses. Y eso pasaba en casi todas las casas" (Participante taller ${ }^{05}, 27$ de mayo de 2017).

“Se trabajaba por 3 meses, otros por seis. Y había quienes hacían el 'año redondo', el año completo afuera” (Entrevistada n³, 29 de mayo de 2017).

Destaca el papel paternal cumplido por la empresa que, asumiendo la ausencia prolongada del trabajador en el núcleo familiar, figura en la Población a modo de suplencia, a través de su personal y/o ciertas acciones de éste.

"Las señoras pasaban 3 meses solas, o más, porque los maridos estaban lejos, en las esquilas...Y el administrador, con la asistente social, recorrían las casas preguntando las necesidades en cada una...Eran unas fichas que llenaba la asistente social" (Participante taller $\mathrm{n}^{0} 1,27$ de mayo de 2017).

"Mi padre era el encargado de recorrer la población todos los días, recorrer, visitar a las personas, entregar la correspondencia que mandaban los... esposos desde las estancias. Él también reparaba los vidrios, la gasfitería, todo ese asunto" (Entrevistada n³, 29 de mayo de 2017).

"La Ganadera también tenía una bodega para abastecer las estancias, entonces mi papá iba y compraba los víveres en esa bodega; los porotos, los garbanzos, la leche condensada, todo lo que era en tarro. También ellos repartían la carne, dos veces por semana, había que ir a buscarla al frente de la población, en un negocio de Miguel Ruiz". (Participante taller $\mathrm{n}^{0} 1,27$ de mayo de 2017).

"De lo que es la ganadera también... Dos veces a la semana los martes y los 
viernes un cuarto de capón o cordero en su minuto" (Participante taller $\mathrm{n}^{0} 5,27$ de mayo de 2017).

Aquel tipo de vinculación trabajador-empresa sería, entonces, un elemento que permitiría construir, entre vecinos -y entre vecinos y empresa-, lo que se ha señalado anteriormente como "una comunidad de destino" (Frey, 1987). La misma que se rompió irreparablemente al diferenciarse los destinos, primero de la empresa y sus trabajadores, y como resultado de ello, de los vecinos-trabajadores entre sí. En el primer caso, la lógica del compromiso se diluyó cuando la empresa ya no obtenía beneficios de ese vínculo; y en el segundo, se fue haciendo imposible mantenerlo al perderse los anclajes espaciales que los sustentaban y permitían su reproducción. Cada vecino-trabajador de aquella empresa que los mantenía unidos, de pronto pasó a ser un ciudadano, habitante de una ciudad que albergaba a todo un conjunto de otros ciudadanos. Entonces no sólo serían las oficinas de bienestar social, las fiestas y rituales, el trato directo patrón-empleados, los que permitían adhesión y compromiso; también lo serían las formas de localización y radicación del trabajador y, naturalmente, de su entorno familiar. Pero una vez desplazado el principio urbanizador ligado a la empresa, la ciudad continúa desarrollándose según su propia lógica de expansión, ajena a prácticas y representaciones en espacios urbanos derivadas de relaciones de uso (Lefebvre, 2013 [1974]).

Aquello cobra relevancia, dado que un aspecto quizá no planificado por la empresa al momento de conformar la población, lo determinó la ubicación de los terrenos donde se emplazó: en los límites de la ciudad y aislada relativamente de ella. Estas condiciones, llevadas a imágenes que construyen recuerdos, ayudaron sin lugar a duda a reforzar las anheladas formas de vinculación y buena vecindad contraídas.

"És que nosotros éramos como los más alejados de la ciudad, éramos los últimos, nosotros éramos la última y la primera Población fuera de...” (ibíd.).

"No nos sentíamos tan aislados de la ciudad como para decir que vivíamos fuera de ella, pero estábamos lejos..." (Entrevistada n³, 29 de mayo de 2017).

"Yo creo que el hecho de estar aislado hizo mucho para tener esa vida que tuvimos allí" (Entrevistada n²2, 29 de mayo de 2017).

Es claro y evidente que la concreción de la Población no formó parte de un proceso de expansión urbana planificado, antes bien, llegó a conformar un asentamiento relativamente aislado, sólo rodeado por sembradíos y pampa magallánica. Ello permitió su conformación en escenario ideal para desarrollar una vida social intensa hacia su interior, donde se hizo posible el despliegue de una sociabilidad diferente marcada por la familiaridad, cercanía y colaboración, con la respectiva ritualidad que secundaba y reafirmaba estos valores. 


\section{Discusión: El olvido como estrategia, la memoria como resistencia}

Las imágenes y construcciones de sentido expresadas apelan a destacar aquellas cualidades que también podrían formar parte de los soportes de la concepción más tradicional de 'barrio', en su versión de refugio dentro de la ciudad donde se produce un conjunto de sociabilidades diferentes, más próximas, e intermediadoras entre las relaciones públicas y las privadas. En la Población Obrera esta sensación de abrigo por intensidad de vínculos será el detonante de un fuerte sentido de pertenencia y membresía a un espacio determinado, el que se vuelve un 'lugar' afectivo al estar lleno de símbolos reconocibles y familiares (Fig. 6). La experiencia colectiva se elabora así por acumulación de varias experiencias biográficas cuyo común denominador será la intensidad del lazo que pone en común a sus habitantes a través de gestos y rituales cotidianos. De ahí también la fuerza de la categoría de 'vecino', aquel con quien se tienen interacciones cara a cara frecuentes, aunque no necesariamente exista algún tipo de unión en base a la consanguineidad. En la Población, a pesar del tiempo transcurrido, se recuerdan los apellidos que otorgaban condición familiar a las distintas viviendas, dando por entendido que éstas existían en la medida en que eran 'la casa de...'. Podemos decir que el espacio residencial habitacional cobra sentido de realidad cuando alguien lo percibe como habitado, en este caso, ni siquiera ocupado por alguien de forma individual, sino por un conjunto familiar.

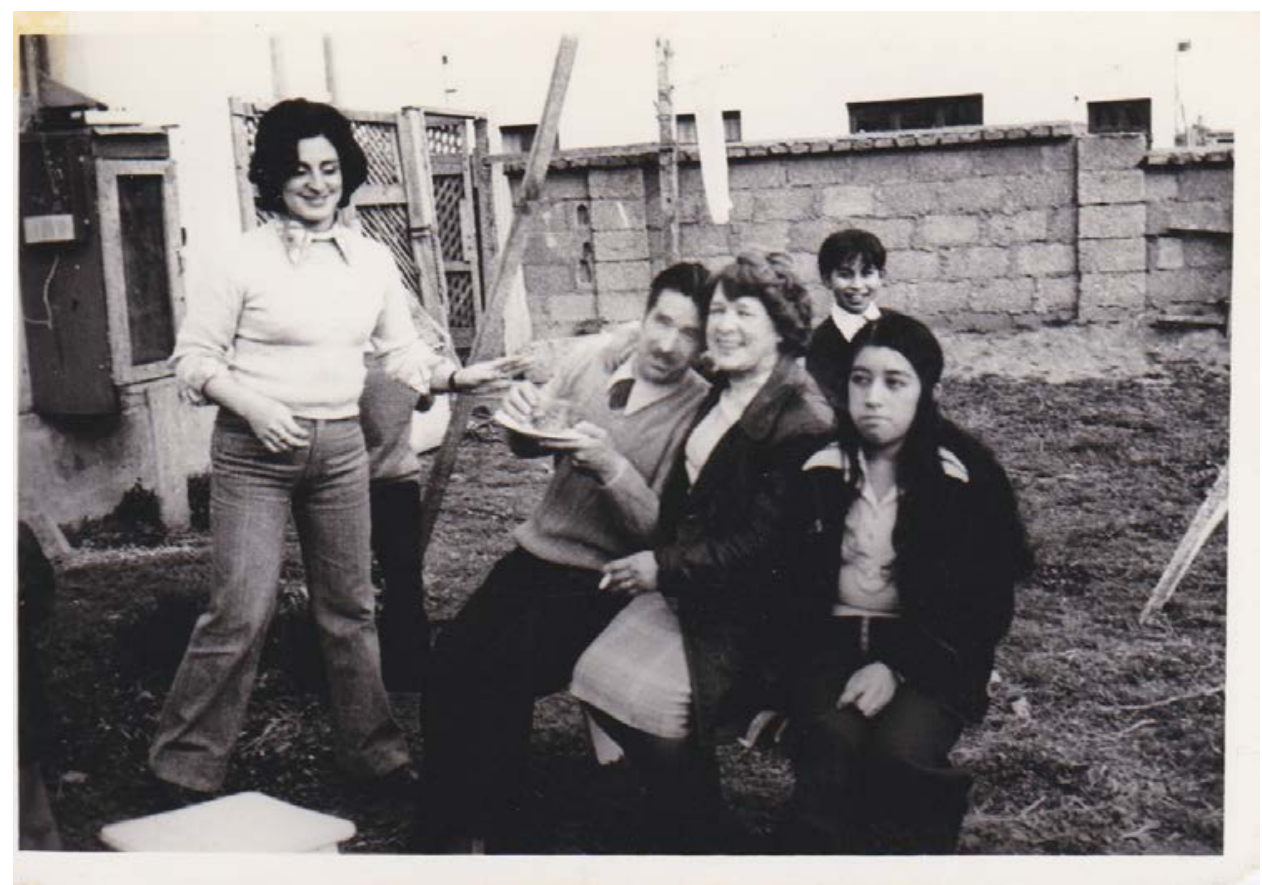

Fig. 6. Fotografía de una reunión familiar en la vivienda de la familia Flores Alarcón (1976). Fuente: Gentileza de Margarita Alarcón Flores. 
Las lógicas de despliegue de los principios del paternalismo industrial se conforman como piezas importantes en esta consolidación de vida barrial, en tanto aglutinantes de una comunidad donde imperarían valores como el respeto mutuo entre desconocidos que se vuelven vecinos. De esta manera, los diferentes espacios barriales se transforman en lugares, ya no neutros, sino más bien escenarios de experiencia colectiva (Ibarra, 2013; Folchi, 2013; Vergara, 2013), principalmente la plaza y los exteriores de las viviendas. Esto, más allá del teórico objetivo primordial ligado a la implantación de las dinámicas del paternalismo industrial que buscaban básicamente la fijación de mano de obra, en tanto forma de control que adquiría un cariz social ejercido por un modelo de productividad (Garcés, 2003; Venegas \& Morales, 2014; Godoy, 2015).

El desarrollo de esta línea de pensamiento sigue una lógica inequívoca. Efectivamente, la creación y conformación del sector asociado a ciertos principios del paternalismo industrial permitió, durante un amplio período, mantener cubierto todo un abanico de aspectos básicos de los trabajadores lo que, en estricto rigor, se traducía en que sus problemas domésticos quedaban bajo un dominio de orden administrativo, en lo que se conoce como una forma de control social blanda. En este caso, el acceso a la vivienda (bajo la figura de un "arriendo" módico) y su mantención; además de la sede vecinal, la maestranza y el apoyo en festividades. A cambio estaba el respeto por parte de los beneficiarios de una moral disciplinada, no sólo vinculada a las horas de trabajo, sino también a los tiempos del no-trabajo (Sierra, 1990; Mantecón, 2010), motivando una vida comunitaria tranquila y solidaria.

Pero existe un además que emerge también a partir de lo señalado en los relatos. En la apropiación de un espacio construido, no obstante que producido por una industria local, los ex-habitantes de la Población reconocen y describen una realidad social cotidiana creada activamente por ellos mismos, y no tanto por la empresa, que aparece como un actor secundario en la elaboración de valoraciones sociales dentro de aquel espacio construido. Dicho en términos del sociólogo francés H. Lefebvre (2013 [1974]), la práctica espacial del espacio percibido, que deriva hacia los espacios de representación -cual espacios físicos a los que se sobreponen sistemas simbólicos complejos que los convierten en albergue de imágenes que los describen-, logra volver más denso un lugar en términos de los significados que por él se ponen en circulación. Por ello, las representaciones del espacio, en tanto fórmulas concebidas no por los habitantes sino desde afuera, ocupan una línea secundaria.

Lo señalado no implica que la presencia de la empresa sea invisibilizada, ocultada o desvirtuada, sino que aparece igualmente como un gran paraguas que se sabe existe, aunque no se manifiesta a diario su presencia. Fue, más bien, una institución que cobijó y que buscó a trabajadores capaces y calificados, para protegerlos a ellos y a sus familias. En ese sentido, la práctica empresarial cobra vida, por ejemplo, a través de la figura del chofer de la gerencia, que tenía el único teléfono en el barrio; aparece también a través de los regalos navideños que eran "para todos los mismos", sin distinción; o por medio de las figuras de la asistente social y del "wachimán" (watchman), encargado de velar por reparaciones y cuidados de las viviendas. 
Desde el punto de vista de los habitantes, la mirada es re-significada. Asumen el rol de la asistencia social -y del “wachimán”-, en la medida en que permiten paliar la ausencia de los trabajadores jefes de familia; no sin recelo o distancia en ciertas ocasiones. Pero también valoran el que no se hicieran distinciones en los regalos, interpretándolo como algo natural y normal de una época en que las distinciones se olvidaban. También reconocen la buena voluntad del chofer para prestar el teléfono, o en ocasiones el mismo vehículo, en su condición de buen vecino, antes que de buen empleado. Así puede entenderse que los habitantes del barrio absorben los marcos de la disciplina social paternalista, y sus exigencias, pero sin con ello caer en la obediencia acrítica, automatizada y servil en relación a la empresa ganadera. Como ya ha sido señalado por Mantecón (2010), el disciplinamiento social requiere de adhesión, consenso, aceptación, pero también participación, entendiendo ésta como una forma de expresión de una sociedad no totalmente disciplinada y reducida a una obediencia acrítica o respondiendo de forma automática a los valores que se proyectan desde arriba.

Por eso, en este complejo proceso de construir vida social en la Población, podemos decir que fue un paso importante la elaboración, por parte de los residentes, de su propio marco de relaciones sociales. El mismo que hoy es puesto en valor, porque pobló su cotidianeidad, acogiendo sus propias representaciones y, por sobre todo, posibilitando la creación de los espacios de representación que cobijaron los valores sociales que buscan trascender. Será precisamente este marco de relaciones, surgido al alero de las condiciones que la industria ofrecía, el que entrará en crisis en un determinado momento confusamente señalado: según la memoria grupal, será cuando la empresa decide desprenderse de las viviendas, poniéndolas en venta en condiciones de mercado, sin excepciones. Pero también podría coincidir con la propia desaparición de la industria y, por ello, con el fin del paraguas que las cobijaba a través de formas paternalistas que articulaban la cohesión social.

Puede ser este el correlato de la desindustrialización que, en esa coyuntura, produce un quiebre inevitable entre los marcos de experiencia y el proyecto de futuro de uno y otro -empresa y vecinos. Sus respectivos intereses no sólo siguen caminos distintos, sino que en más de un sentido se contraponen ya que, en este intervalo, se rompe el aislamiento que mantenían sus habitantes por efecto de las propias dinámicas del paternalismo industrial y la comunidad se ve obligada a entrar en proceso de transformación forzada. Por otro lado, se debe considerar que la ciudad había comenzado a variar su dimensión, y la propia producción del espacio cercano ya no era la misma que reforzaba el recogimiento, puesto que el barrio dejó de ser aquel lugar dentro, pero fuera de la ciudad al mismo tiempo. Por último, con el paso de los años, será la arquitectura de lugar la que evidencie las transformaciones más visibles (Fig. 7). Casas demolidas, otras reformadas, van diluyendo no sólo perceptiva, sino que también físicamente, el otrora reconocible barrio donde se forjó una comunidad de vecinos. 


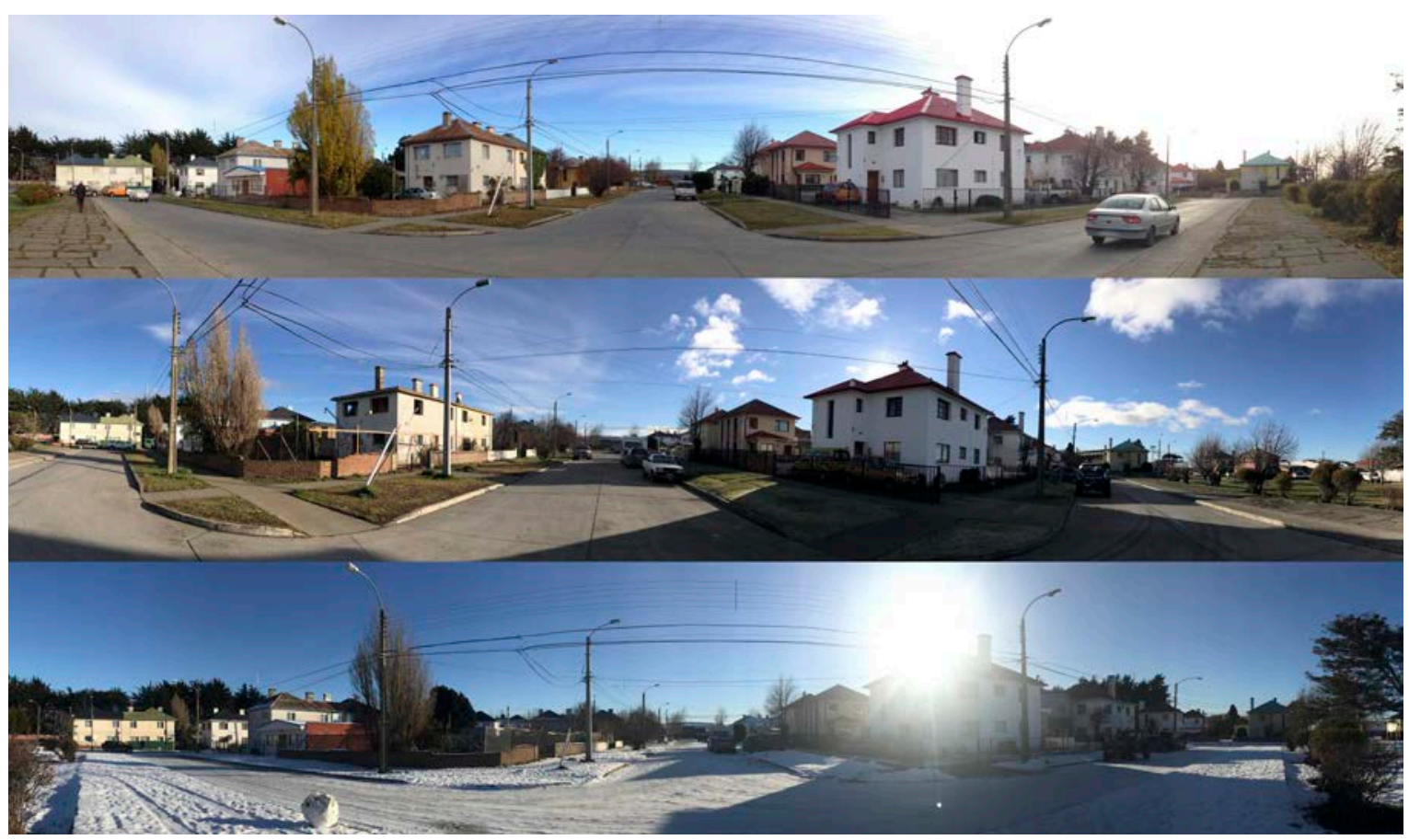

Fig. 7. Fotografías panorámicas de proceso de demolición de viviendas pareadas en calle Julio Lillo, desde 2016 (imagen superior), 2017 (imagen central) hasta 2018 (imagen inferior).

Fuente: Archivo fotográfico Daniela Ambrosetti Garrido.

\section{CONCLUSIONES}

Asumiendo la definición de patrimonio como una noción compleja, el patrimonio industrial muchas veces ha sido visto como antiestético o portador de valores ambivalentes, provocando debates y resistencias. Al mismo tiempo, se ha ido consolidando una cierta institucionalidad que renueva el énfasis por su protección, conservación y difusión (Carta de Nizhny Tagil en 2003, o los Principios de Dublín en 2011). Ello, bajo la convicción de que su propia complejidad e incertidumbre valórica le otorga una notoria vulnerabilidad al sentido de continuidad histórica que representan, no sólo sus maquinarias y estructuras de producción, sino también todo el legado social y cultural que dio forma a la vida de diversas comunidades. La memoria colectiva construida por antiguos pobladores de la Población Obrera Sociedad Explotadora de Tierra del Fuego, bajo el manto de una particular forma de desarrollo industrial en Magallanes, sintetiza también esta ambivalencia y vulnerabilidad. No sólo es un determinado modo de producción el que sale a la luz, sino también todo un complejo entramado de relaciones sociales que compusieron una organización social, con marcados componentes afectivos, que hoy cobra valor agregado.

Sin duda es precisamente esta organización, sostenida en estructuras valóricas, la que crea todo un conjunto de experiencias colectivas apreciadas como únicas y propias, y que sustenta la memoria que se contrasta con un presente. La solidaridad, fraternidad, 
camaradería y complicidad entre sus habitantes conformaron categorías de 'vecino', allí donde sólo previamente existía la de 'colega'. Los rituales y celebraciones permitieron enfatizar y actualizar estos sentimientos, no sólo en los más simpatizantes a tradiciones propias del mundo contemporáneo como navidades, cumpleaños y otros, sino también en la cotidianeidad de juntarse en la plaza, de saludar al encontrarse, o el detenerse a conversar en la antesala de la vivienda.

El patrimonio no cae 'por su propio peso', sino que es el producto de una elección de un grupo social que refleja, a través de la relación con su pasado, su presente. En este sentido, asistimos en este caso a un proceso de valoración de un conjunto de prácticas, acontecimientos y formas de sociabilidad, por parte de quienes las vivieron. Además, observamos que este proceso va de la mano con el realce de una determinada forma de apropiación de un espacio específico y delimitado: el conjunto de viviendas, predios y manzanas -una trama vial y su plaza como ícono-, construido para trabajadores y empleados de la Sociedad Explotadora según una planificación urbanística y arquitectónica en donde, tanto experiencias como recuerdos, van encontrando su lugar sin disociarse del espacio materializado. En este sentido, el conjunto de referencias aquí explicitadas habla de una "apropiación” del espacio edificado por parte de vecinos que lo convirtieron en "propio" a partir de habitarlo. De este modo, un hábitat construido se transformó en un espacio vivido.

Simultáneamente, el relato grupal rememora un tiempo que ha sido desanclado del mismo espacio en que se creó, y en el que se reprodujo aquel mundo, por lo que se asume que ya no puede ser duplicado. La causa de esto apela a la dispersión de los propios sujetos, pero también a la cada vez más visible transformación del marco físico, así como a los cambios urbanísticos generalizados ocurridos en el entorno de la ciudad. Entonces, este pasado recuperado busca su lugar en el único lugar que hoy se le ofrece: como patrimonio intangible, o inmaterial, que describe un tiempo que se busca transmitir de generación en generación para así otorgarle algún futuro. Sin embargo, el sentido de continuidad, imprescindible para la reproducción de éste, parece estar roto y, por ello, sólo puede ser evocado a través de relatos que describen un mundo sin demasiada relación con el presente.

Entonces, su consideración como patrimonio intangible se vuelve compleja al reflejar esta doble condición de la memoria colectiva. Por una parte permite, a través de la oralidad, actualizar símbolos y valoraciones posibles de ser transmitidos a las nuevas generaciones; pero, al mismo tiempo, estas mismas narraciones no van encontrando en el espacio el lugar donde se escenificaban sus valores constitutivos. En este sentido, si las formas arquitectónicas van mutando, la oralidad peligra de conformarse como mito o leyenda.

En ello reside la amenaza para esta memoria colectiva: tal como ocurre muchas veces en la actualidad, lo evocado se ve empujado a buscar su lugar en una figura patrimonial, porque engloba todo aquello que sólo puede encajar en los tiempos actuales como sobrevivencia, tradición e historia; algo rescatado de otro tiempo que busca reinventarse en un espacio hoy inexistente. Hasta cierto punto, este ejercicio puede entenderse como una estrategia 
seguida por vecinos y ex-vecinos, ligados entre sí, y que se ven enfrentados a un escenario en el que no logran situarse. A través de la evocación intentan acercarse a un mundo que ya no es posible visualizar, y menos reproducir, que por el contrario, frente a la distancia espacial -representada por los cambios arquitectónicos de la Población y urbanísticos de la ciudad-, no parece haber mucho por hacer, más que resignarse y confrontar las demoliciones con los recuerdos. Así, la narrativa refleja a quienes no encuentran un lugar en el mundo contemporáneo.

De ello surge una sensación de vacío del sentido de identidad, que compartida, lleva a formar parte de un colectivo para poseer una historia hacia atrás, pero también, para componer y visualizar a través de ella, un porvenir. Si asumimos que el objetivo de toda identidad es poder proporcionar un proyecto de futuro común a través de la construcción de un pasado que lo enmarque, en el caso revisado, al no poder reproducirse sus principios articuladores -un marco de relaciones, una arquitectura de lugar y una producción del espacio social acorde-, sólo queda la evocación como posibilidad de valoración de un intangible. El problema recae en que, como su contexto empieza a diluirse entre retroexcavadoras, sigue aumentando la brecha entre la actualidad y lo relatado; por tanto, buscar un proyecto de futuro, se complejiza y permanece nebuloso. Frente a eso, la ahora ex-comunidad de vecinos parece haber escogido el olvido del presente como estrategia y la memoria del pasado como resistencia.

\section{REFERENCIAS}

Acevedo, P., \& Rojas, C. (2014). Campamentos enapinos en Tierra del Fuego. Perspectivas desde el patrimonio industrial. Sophia Austral, 14, 85-97.

Álvarez, M. (2008). Patrimonio industrial. Un futuro para el pasado desde la visión europea. APUNTES, 21(1) 6-25.

Ambrosetti, D., Cvitanic, B., \& Matus, D. (2016). Población Obrera Sociedad Explotadora de Tierra del Fuego: expresión espacial de paternalismo industrial en Punta Arenas. Sophia Austral, 18, 111-135.

Augé, M. (1998). Las formas del olvido. Barcelona: Editorial Gedisa.

Baeriswyl, D. (2001). Arquitectura en Punta Arenas. Primeras edificaciones en ladrillos. 18921935. Punta Arenas, Chile: Imprenta La Prensa Austral.

Bascopé, J. (2008). Pasajeros del poder proletario: La Sociedad Explotadora de Tierra del Fuego y la biopolítica estanciera (1890-1920). Magallania, 36(2), 19-44.

Bascopé, J. (2010). Sentidos coloniales. El oro y la vida salvaje en Tierra del Fuego, 1880-1914. Magallania, 38(2), 5-26.

Bayer, O. (2009). La Patagonia rebelde. Coyhaique: Talleres gráficos F.U.R.I.A.

Cvitanic, B., \& Matus, D. (2018). Industria y hábitat colectivo en la Región de Magallanes: dinámicas y singularidades de un modo de ocupación territorial, 1885-1971. Revista 
180, 42, 36-48.

Cvitanic, B., Matus, D., Ambrosetti, D., Herrera, R., \& Bustos, A. (2018). Hidrocarburos. En A. Brito, G. Cerda, P. Fuentes \& L. Pérez (Eds.), Industria y habitar colectivo. Conjuntos habitacionales en el sur de Chile. Concepción: STOQ Editorial.

DIBAM (2005). Memoria, cultura y creación. Lineamientos políticos. Santiago de Chile: Dirección de Bibliotecas, Archivos y Museos.

DOM (1952). Expediente No 200 Población Explotadora. Dirección de Obras Municipales, I. Municipalidad de Punta Arenas.

Durán, F. (1943). Sociedad Explotadora de Tierra del Fuego. 1893-1943. Valparaíso: Universo. El Magallanes (1953). Hoy se inauguró la población obrera construida por la Sociedad Explotadora de Tierra del Fuego, Punta Arenas, 17 de enero de 1953, p. 7.

Folchi, M. (2013). Historia material de Potrerillos: minería, industria y vida cotidiana en un complejo minero-industrial (1916-1959). Universidad de Chile. Informe de seminario de grado para optar al grado de Licenciado en Historia.

Frey, J. P. (1987). Société et Urbanistique Patronale. Thèse d'Etat en Lettres et Sciences Humaines. Université de Paris 10-Nanterre.

Fugellie, S. (1995). 50 Años de Comunidad Petrolera. Punta Arenas: Empresa Nacional del Petróleo.

Furche, C. (2017). La transformación social, política y cultural más relevante del siglo XX. Revista Anales. A 50 años de la Reforma Agraria, 12, 113-120.

Garcés, E. (2003). Las ciudades del cobre. Del campamento de montaña al hotel minero como variaciones de la company town. EURE, XXIX, 88, 131-148.

Garcés, E., Kroeger, F., Martinic, M., Piwonka, N., \& Cooper, M. (2013). Tierra del Fuego. Historia, Arquitectura y Territorio. Santiago, Chile: ARQ ediciones.

Godoy, M. (2015). Las casas de la empresa: Paternalismo industrial y construcción de espacio urbano en Chile. Lota, 1900-1950. UNIVERSUM, 1, 115-136.

Halbwachs, M. (2004). La memoria colectiva. Zaragoza: Prensa Universitaria Zaragoza.

Hidalgo, R. (2005). La vivienda social en Chile y la construcción del espacio urbano en el Santiago del siglo XX. Santiago: Pontificia Universidad Católica de Chile.

Hobsbawm, E. (1998). La Era del Imperio, 1875-1914. Buenos Aires, Argentina: Grupo Editorial Planeta.

Homobono, J. (2008). Del patrimonio cultural al industrial: Una mirada socioantropológica. En X. Pereiro, S. Prado \& H. Takenaka (Eds.), Patrimonios culturales: educación e interpretación. Cruzando límites y produciendo alternativas. Donostia: Ankulegi Antropologia Elkartea.

Ibarra, C. (2013). Una memoria para los refineros. Valparaíso: Ediciones Universidad de Valparaíso.

Jelin, E. (2002). ¿De qué hablamos cuando hablamos de memoria? Madrid: Siglo XXI.

Jofré, J. (1995). Forjadores de la actividad petrolera en Chile. Santiago, Chile: Empresa Nacional 
del Petróleo.

Lefebvre, H. (2013 [1974]). La producción del espacio. Barcelona: Capitán Swing libros.

Maillard, C. (2011). Construcción social del patrimonio. En D. Marzal (Ed.), Hecho en Chile. Reflexiones en torno al patrimonio cultural. Fondart: Santiago.

Mantecón, T. (2010). Formas de disciplinamiento social. Perspectivas históricas. Revista de Historia Social y de las Mentalidades. Vol. 14. No2: 263-295.

Martinic, M. (1980). Ocupación del ecúmene de Magallanes, 1843-1930. La colonización de las áreas marginales. Anales del Instituto de la Patagonia, 11, 7-46.

Martinic, M. (1993). Historia del petróleo en Magallanes. Punta Arenas, Chile: Empresa Nacional del Petróleo.

Martinic, M. (2003). La minería aurífera en la región austral americana (1869-1950). Historia, $36,219-254$.

Martinic, M. (2005). Historia del petróleo en Magallanes. Punta Arenas: La Prensa Austral.

Martinic, M. (2011). Recordando a un imperio pastoril: La Sociedad Explotadora de Tierra del Fuego (1893-1973). Magallania, 39(1), 5-32.

Martinic, M. (2011). Documentos inéditos para la Historia de Magallanes. Las vivencias patagónicas de Mateo Ivanovic Sapunar. Magallania, 39(1), 277-299.

Martinic, M. (2017). Un novedoso mapa manuscrito del Seno Última Esperanza (1895). Magallania, 45(2), 5-10.

Matus, D., \& Cvitanic, B. (2016). La Empresa Nacional del Petróleo y la construcción de un paisaje urbano: Barrios de la ciudad de Punta Arenas. En G. Ciselli \& V. Navarro (Eds.), Paisajes culturales y patrimonio: expresiones de la cultura territorial. Río Gallegos: Universidad Nacional de la Patagonia Austral.

Nicholls, N. (2010). La Sociedad Ballenera de Magallanes: de cazadores de ballenas a "Héroes" que marcaron la soberanía nacional, 1906-1916. Historia, 43 (I), 41-78.

Pardo, C. (2016). El patrimonio industrial en España. Paisajes, lugares y elementos singulares. Madrid: Editorial Akal.

Registro Conservatorio de propiedad (1966) Conservador de Bienes Raíces de Magallanes, Números: 587-588; 590; 597-598; 609; 613-614; 617-621; 652-661; 668-670; 672-678; 683-684; 689-700; 703-709; 746-747; 754-756; 758; 764-766.

Registro Conservatorio de propiedad (1967) Conservador de Bienes Raíces de Magallanes, Números: 17-18; 79-82; 103; 190-191; 203; 245; 268; 351; 389; 395-404; 585; 690; 867. Registro Conservatorio de propiedad (1968) Conservador de Bienes Raíces de Magallanes, Números: 90; 148-149; 228; 389; 390-391; 422-432; 491; 628; 2097.

Registro Conservatorio de propiedad (1969) Conservador de Bienes Raíces de Magallanes, Números: 82; 201; 330; 639-640.

Registro Conservatorio de propiedad (1970) Conservador de Bienes Raíces de Magallanes, Números: 414-416; 680; 715.

Registro Conservatorio de propiedad (1971) Conservador de Bienes Raíces de Magallanes, 
Números: 407; 479; 655; 820.

Registro Conservatorio de propiedad (1972) Conservador de Bienes Raíces de Magallanes, Números: 564-567; 762; 770; 910; 957; 1076-1080.

Rosa, A., Bellel, G., \& Bakhurst, D. (2000). Memoria Colectiva e Identidad Nacional. Madrid: Biblioteca nueva 2000.

Salazar, G., \& Pinto, J. (2014). Historia contemporánea de Chile II. Actores, identidad y movimiento. Santiago: LOM Ediciones.

Sierra, J. (1990). El obrero soñado. Ensayo sobre el paternalismo industrial Asturias (18601917). Madrid: Siglo XXI.

Venegas, R. (2011). Remembranzas de la Sociedad Explotadora de Tierra del Fuego. Ganadera Tierra del Fuego. Punta Arenas: s/e.

Venegas, H., \& Morales, D. (2014). El despliegue del paternalismo industrial en la Compañía Minera e Industrial de Chile (1920-1940). Historia Crítica, 58, 117-136.

Vergara, Á. (2013). Paternalismo industrial, empresa extranjera y campamentos mineros en América Latina: un esfuerzo de historia laboral y transnacional. Avances del César, 10, 113-128.

Zamora, E. (1975). La evolución urbana de la ciudad de Punta Arenas. Crecimiento entre 1848 y 1975. Anales del Instituto de la Patagonia, 6, 61-92. 